\title{
Pengetahuan terhadap Perkhidmatan Ekosistem dan Sumbangannya kepada Kehidupan Komuniti di Kuala Sepetang, Perak
}

\author{
Mohd Azmeer Abu Bakar ${ }^{1}$, Asyirah Abdul Rahim ${ }^{1}$, Mohammad Izzamil Mohd Nasir ${ }^{1}$ \\ ${ }^{1}$ Bahagian Geografi, Pusat Pengajian Ilmu Kemanusiaan, \\ Universiti Sains Malaysia
}

Correspondence: Asyirah Abdul Rahim (email: asyirah@usm.my)

Received: 17 July 2019; Accepted: 25 February 2020; Published: 27 February 2020

\begin{abstract}
Abstrak
Kemusnahan alam sekitar dan kepupusan biodiversiti telah menjadi suatu isu yang sangat membimbangkan. Keterancaman biodiversiti ini dijangka akan berterusan dan meningkat pada masa akan datang jika tiada tindakan serius yang diambil oleh semua pihak berkepentingan. Kemerosotan dan kepupusan sumber semula jadi yang menjejaskan perkhidmatan ekosistem bukan sahaja menjadi isu dan cabaran di peringkat global, malah turut memberi impak kepada Malaysia. Oleh itu, kajian mengenai tahap pengetahuan komuniti dan sumbangan perkhidmatan ekosistem perlu dilakukan dengan memfokuskan kepada empat kategori perkhidmatan ekosistsem iaitu perkhidmatan-perkhidmatan pembekalan, kawal atur, sokongan, dan budaya. Sejumlah 249 borang soal selidik telah diedarkan secara rawak kepada anggota kuminiti di kawasan Kuala Sepetang, Perak. Data yang diperoleh melalui borang soal selidik ini, dianalisa dengan menggunakan kaedah Indeks Kepentingan Relatif (RII) dalam menentukan kedudukan item dan kategori. Kajian mendapati tahap pengetahuan komuniti setempat terhadap keempat-empat kategori perkhidmatan ekosistem adalah baik iaitu perkhidmatan pembekalan, perkhidmatan kawal atur, perkhidmatan sokongan dan perkhidmatan budaya. Sumbangan perkhidmatan ekosistem sokongan menunjukkan sumbangan terbesar dalam kehidupan harian penduduk dan secara tidak langsung membantu dalam kelangsungan hidup. Alam sekitar semula jadi terbukti menyediakan perkhidmatan ekosistem yang sangat penting dan menjadi elemen yang utama dalam kehidupan harian komuniti tempatan. Perkhidmatan ekosistem bukan hanya memberi perkhidmatan kepada manusia tetapi juga menjadi sistem bantuan kehidupan yang berkualiti.
\end{abstract}

Kata kunci: alam sekitar, sumber semula jadi, komuniti, indeks kepentingan relatif, perkhidmatan ekosistem, pengetahuan 


\title{
Knowledge and Contributions of Ecosystem Services to Community Livelihood at Kuala Sepetang, Perak
}

\begin{abstract}
Environmental destruction and biodiversity extinction have become an issue of grave concern. These threats on biodiversity are expected to continue and increase in the future if no serious actions are taken by stakeholders. Degradation and extinction of natural resources that affect the ecosystem services is not just a global issue and challenge at the global level, it also has an impact on Malaysia. Therefore, there is a need to study on the level of knowledge within the community on the contribution of ecosystem services focusing on four aspect of ecosystem services such as supply, regulatory, support and culture. A total of 249 questionnaire forms were distributed randomly to community members in the area of Kuala Sepetang, Perak. Data obtained through this survey were analyzed using the Relative Importance Index (RII) method in determining the position of items and categories. The study showed that the level of knowledge among the local community on the four ecosystem service categories are good such as supply service, regulatory service, support service and culture service. The support ecosystem service contributed the most towards the daily life of the community and indirectly enhanced their livelihood. Natural environment is proven providing a very important ecosystem service and it is a vital element of the local community daily life. Ecosystem services not only serve people but also become a quality life support system.
\end{abstract}

Keywords: environment, natural resources, community, relative important index, ecosystem services, knowledge

\section{Pengenalan}

Perkhidmatan ekosistem (Ecosystem services, ES) merupakan topik yang semakin diberi perhatian dalam penyelidikan ekologi masa kini dan sering digunakan dalam bidang saintifik (Liu et al., 2012; Villamagna \& Giesecke, 2014; Cruz-Garcia et al., 2017). Pendekatan perkhidmatan ekosistem penting dalam mengenal pasti kepelbagaian manfaat dan sumbangan ekosistem semula jadi termasuklah manfaat yang nyata atau tidak nyata yang menyokong pengurusan bersepadu di peringkat tempatan (Ahammad et al., 2019). Selain itu, perkhidmatan ekosistem juga dapat menunjukkan hubungan yang berlaku antara alam sekitar dengan manusia (Hou et al., 2014) dan berpotensi dalam memberi maklumat mengenai struktur dan fungsi ekosistem serta peranannya dalam menyokong kebajikan dan kesejahteraan hidup manusia.

Namun, perkhidmatan ekosistem saban hari mengalami kemerosotan akibat daripada penggunaan tanpa had oleh manusia (Ostrom, 2008; Rasethe et al., 2013). Sepertimana direkodkan dalam laporan Kualiti Alam Sekitar (2010), sebanyak sepuluh batang sungai di negeri Kedah telah tercemar dan 209.44 kilometer persegi kawasan sumber semula jadi telah mengalami kerosakan akibat daripada penggunaan manusia tanpa kawalan. Hal ini akan menjejaskan keseimbangan ekosistem serta kualiti sumbangan yang disediakan oleh alam sekitar kepada manusia. Sehubungan itu, Raman dan Bakar (2019) turut menyatakan bahawa pelbagai usaha dan inovasi telah dibuat bagi menyelesaikan masalah alam sekitar, namun masih kurang memberikan kesan kerana masalah ini turut terjadi disebabkan sikap dan tingkah laku manusia itu sendiri yang tidak cakna dan kurang pengetahuan tentang alam 
sekitar di sekeliling mereka. Oleh itu, penilaian pengetahuan terhadap perkhidmatan ekosistem dalam kalangan penduduk perlu dilakukan supaya dapat memberi maklumat tentang fungsi dan manfaat yang diperoleh oleh alam sekitar dalam kehidupan mereka.

\section{Konsep perkhidmatan ekosistem}

Berdasarkan Millennium Ecosystem Assessment, MEA (2005), perkhidmatan ekosistem (ES) merupakan faedah yang disediakan oleh ekosistem yang memberi sumbangan kepada kesejahteraan hidup manusia. Konsep ES dikelaskan kepada empat kategori iaitu perkhidmatan pembekalan (provisioning service) seperti makanan, air; perkhidmatan kawal atur (regulating service) seperti pengawalan banjir, kemarau dan penyakit; perkhidmatan sokongan (supporting service) seperti kitaran nutrien, pembentukan tanah; dan perkhidmatan budaya (cultural service) seperti rekreasi, kesihatan dan nilai estetika (Liu et al., 2010).

Konsep ES telah dikenali sebagai satu cara untuk merangka dan menerangkan set komprehensif manfaat yang manusia dapat daripada alam semula jadi. Hal ini termasuk barangan biasa yang diiktiraf seperti kayu dan air tawar, serta proses seperti peraturan iklim dan penulenan air, dan estetik, rohani, dan manfaat budaya (Smith et al., 2011). ES mempunyai banyak definisi dan konsep, klasifikasi dan kategori yang berbeza yang telah dibangunkan beberapa dekad lalu (Villamagna \& Giesecke, 2014). Jadual 1 menunjukkan definisi dan konsep ES oleh beberapa pengkaji sebelum ini.

Jadual 1. Definisi dan konsep perkhidmatan ekosistem

\begin{tabular}{|c|c|}
\hline Pengkaji & Definisi dan Konsep ES \\
\hline Kuhn (2014) & $\begin{array}{l}\text {...."satu cara untuk menganalisis dan memahami interaksi kompleks } \\
\text { yang berlaku dalam sistem manusia dengan alam semula jadi". }\end{array}$ \\
\hline $\begin{array}{l}\text { Howe, Suich, Vira, \& } \\
\text { Mace, (2014) }\end{array}$ & ....."menyediakan faedah untuk kesejahteraan hidup manusia". \\
\hline Kalaba (2013) & $\begin{array}{l}\text {...."menyediakan pelbagai perkhidmatan yang berguna dan penting } \\
\text { dalam kehidupan manusia". }\end{array}$ \\
\hline Crossman et al. (2013) & $\begin{array}{l}\text {...."menyediakan pelbagai faedah dan perkhidmatan kepada } \\
\text { masyarakat dan perkhidmatannya menyumbang terus kepada } \\
\text { kesejahteraan hidup dan kekayaan ekonomi". }\end{array}$ \\
\hline $\begin{array}{l}\text { Felix \& Burkhard } \\
\text { (2012) }\end{array}$ & $\begin{array}{l}\text {...."fenomena ekologi yang menyokong pergantungan manusia sebagai } \\
\text { indikator ekologi". }\end{array}$ \\
\hline Liu et al. (2010) & $\begin{array}{l}\text {...."faedah dan manfaat daripada alam semula jadiuntuk masyarakat } \\
\text { manusia". }\end{array}$ \\
\hline MEA (2005) & $\begin{array}{l}\text {....."keuntungan yang diperolehi manusia daripada ekosistem semula } \\
\text { jadi". }\end{array}$ \\
\hline
\end{tabular}

\section{Perkhidmatan pembekalan}

Perkhidmatan pembekalan dalam MEA (2005) merupakan perkhidmatan yang pelbagai dan bergantung kepada produk-produk individu dan boleh termasuk kepada pengeluaran makanan, kayu kayan, dan beberapa jenis tumbuhan yang digunakan untuk tujuan perubatan termasuklah semua bahan output dan biotik yang bertenaga daripada ekosistem. Bahan output 
dan biotik ini merupakan perkara yang boleh ditukar atau diniagakan, dimakan atau digunakan secara langsung oleh manusia (Haines-young \& Potschin, 2013). Price, (2014) pula berpendapat bahawa perkhidmatan pembekalan menjana produk fizikal yang boleh digunakan dan dikenali sebagai barang-barang, termasuk kayu dan produk bukan kayu. Haines-young \& Potschin (2013) telah membahagikan kategori perkhidmatan pembekalan kepada empat bahagian utama, iaitu pemakanan (termasuk semua output ekosistem yang digunakan secara langsung atau tidak langsung sebagai bahan makanan seperti air yang boleh diminum); bekalan air yang merangkumi kegunaan manusia dan yang lain; bahan (biotik) yang digunakan dalam pembuatan barangan; dan biotik untuk sumber tenaga boleh diperbaharui. Watson et al. (2005) pula menyatakan bahawa, perkhidmatan pembekalan ekosistem telah menyediakan; makanan dan serat, bahan bakar, sumber genetic termasuk gen dan maklumat genetic, biokimia ubat-ubatan dan farmaseutikal, sumber hiasan daripada produk haiwan, dan air bersih.

\section{Perkhidmatan kawal atur}

Perkhidmatan kawal atur termasuk dalam kapasiti ekosistem yang menyerap atau proses sisa produk yang telah memberi sumbangan atau faedah kepada kesejahteraan manusia dengan mengawal persekitaran seperti peraturan iklim global dan lokal (Haines-Young \& Potschin, 2010). Perkhidmatan kawal atur juga turut merangkumi penyelenggaraan, fungsi kualiti alam sekitar dalam berhubung dengan udara, ciri-ciri air dan perlindungan terhadap bahaya.

MEA (2005) mendefinisikan perkhidmatan kawal atur sebagai perkhidmatan yang mengatur seperti penyakit dan peraturan iklim, pemprosesan sisa, dengan melebihi keupayaan ekosistem untuk menyediakan perkhidmatan ini. Kebanyakan perubahan untuk mengawal atur perkhidmatan adalah keputusan yang tidak disengajakan serta tindakan yang diambil untuk meningkatkan pembekalan perkhidmatan peruntukan. Mengawal selia perkhidmatan adalah proses yang meningkatkan fizikal persekitaran manusia untuk tujuan tertentu seperti kesan ke atas sifat-sifat atmosfera, saluran air dan permukaan tanah, dan kehidupan biologi yang mempunyai kepentingan ekonomi (Price, 2014). Watson et al. (2005) telah mengkelaskan perkhidmatan kawal atur seperti berikut; penyelenggaraan udara yang berkualiti, peraturan iklim, kawal selia bekalan air, kawalan hakisan, pembersihan air dan rawatan bahan buangan, peraturan penyakit manusia, kawalan biologi, pendebungaan dan perlindungan bencana ribut.

\section{Perkhidmatan sokongan}

Perkhidmatan sokongan merupakan perkhidmatan yang diperlukan untuk pengeluaran semua perkhidmatan ekosistem yang lain. Perkhidmatan sokongan berbeza daripada perkhidmatan yang lain kerana membantu fungsi ekosistem, tanpa memberikan apa-apa produk atau mengubah mana-mana keadaan alam sekitar malah dapat memberi manfaat secara langsung kepada manusia. Sebagai contoh, perkhidmatan sokongan adalah pengeluaran oksigen ke atmosfera, pembentukan tanah dan penyimpanan, kitaran nutrient dan penyediaan habitat (Watson et al., 2005). Perkhidmatan sokongan adalah diperlukan untuk pengeluaran semua perkhidmatan ekosistem lain. Perkhidmatan ini berbeza daripada peruntukan, mengatur, dan kebudayaan yang membawa kesan secara tidak langsung atau berlaku dari masa ke masa yang sangat lama, sedangkan perubahan dalam kategori yang lain mempunyai kesan yang agak langsung dan jangka pendek kepada manusia (MEA, 2005). Perkhidmatan sokongan merupakan perkhidmatan yang menyokong biodiversiti untuk meneruskan kehidupan dan menjadi asas penting dalam banyak perkhidmatan lain serta aktiviti-aktiviti manusia sama ada di bandar mahupun di luar bandar (Shackleton et al., 2008). 


\section{Perkhidmatan budaya}

Perkhidmatan budaya merupakan keupayaan ekosistem untuk memberi manfaat yang tidak nyata atau intangible kepada masyarakat. Kategori perkhidmatan budaya semakin mendapat perhatian sejak beberapa tahun kebelakangan ini berbanding kategori perkhidmatan ekosistem yang lain. Budaya manusia dipengaruhi oleh ekosistem, dan perubahan ekosistem boleh mempunyai kesan yang besar ke atas identiti kebudayaan dan kestabilan sosial. Budaya manusia, sistem pengetahuan, agama, nilai-nilai warisan, interaksi sosial, dan perkhidmatan yang berkaitan ameniti (seperti keseronokan estetik, rekreasi, kesenian dan kepuasan rohani, dan perkembangan intelek) sentiasa dipengaruhi dan dibentuk oleh sifat ekosistem. Perkhidmatan budaya juga merujuk kepada modal atau output ekosistem semula jadi yang mempunyai simbolik, kebudayaan atau kepentingan intelektual untuk masyarakat (HainesYoung \& Potschin, 2010). Kebudayaan adalah pengalaman deria ekosistem yang meningkatkan kesejahteraan manusia, estetika dan rohani. Menurut Watson et al. (2005) pula, perkhidmatan budaya adalah faedah bukan kebendaan yang diterima oleh manusia daripada ekosistem melalui pengayaan rohani, perkembangan kognitif, renungan, rekreasi, dan pengalaman estetik termasuklah; kepelbagaian budaya (kepelbagaian ekosistem), nilai-nilai rohani dan keagamaan, sistem pengetahuan (tradisional dan formal), inspirasi, nilai-nilai estetika, hubungan sosial, rasa tempat (sense of place), nilai warisan budaya, dan rekreasi dan ekopelancongan.

\section{Konsep pengetahuan}

Pengetahuan didefinisikan sebagai kapasiti untuk memperoleh, mengekal dan menggunakan maklumat; campuran kefahaman, pengalaman, kearifan dan kemahiran. Penguasaan pengetahuan ini memerlukan dua asas utama yang saling melengkapi iaitu konsep sesuatu objek itu difikirkan secara keseluruhan di mana hal ini memerlukan kebolehan daya fikir, manakala yang kedua ialah konsep yang diperolehi melalui persepsi dan tanggapan, imaginasi, memori, pengadilan, konsep yang abstrak dan pertimbangan (Jamilah et al., 2011). Dalam bidang perubatan, pengetahuan ialah keupayaan untuk mendapatkan, mengekalkan dan menggunakan maklumat; ia adalah gabungan pemahaman, pengalaman, kecerdikan dan kemahiran. Penyelidikan terdahulu tentang tingkah laku alam sekitar telah mengkaji pelbagai faktor yang mempengaruhi tingkah laku seperti pengetahuan alam sekitar atau kemampuan untuk memahami dan menilai kesan terhadap alam sekitar (Jamilah et al., 2011).

Kepentingan pengetahuan dan kesan kekurangan pengetahuan dalam proses membuat keputusan telah dibuktikan dalam pelbagai kajian. Menurut Chan dan Lau (2000), pengetahuan tentang alam sekitar turut mempengaruhi pengguna untuk mengamalkan tingkah laku yang mesra alam. Begitu juga dengan Laroche et al. (2001) berpendapat bahawa kesedaran alam sekitar dan tingkah laku telah dipengaruhi oleh nilai-nilai, sikap dan pengetahuan tentang alam sekitar. Menurut Mohamad dan Teoh (2006), kebanyakan responden di Malaysia mempunyai tahap keprihatinan yang tinggi terhadap masalah alam sekitar. Mereka juga berpendapat bahawa pihak kerajaan, pihak pengeluar, pengiklan dan sekolah harus memainkan peranan dalam usaha melindungi alam sekitar.

Selain itu, persepsi komuniti setempat terhadap konsep perkhidmatan ekosistem adalah penting untuk menilai dimensi sosio-budaya konsep ini (Sodhi et al., 2010) dan maklumat berkaitan persepsi ini boleh menentukan arah tuju pembangunan masa hadapan (Hashim et al., 2019). Tambahan pula, persepsi terhadap pemahaman sosio-budaya mengenai hubungan manusia dan alam sekitar juga penting dalam meningkatkan tindak balas menyeluruh dalam pengurusan ekosistem yang lestari (Aguado et al., 2018). Namun, menurut 
Delgado dan Marin (2016), pemahaman tentang bagaimana perkhidmatan ekosistem berpotensi dalam meningkatkan kesejahteraan manusia masih lagi rendah. Oleh itu, artikel ini bertujuan untuk mengenal pasti tahap pengetahuan komuniti mengenai konsep perkhidmatan ekosistem dan sumbangan perkhidmatan ekosistem kepada kesejahteraan hidup mereka. Hal ini adalah penting untuk mengenal pasti maklumat, pengetahuan dan kesedaran tentang isuisu alam sekitar khususnya dalam konteks perkhidmatan ekosistem.

\section{Metodologi}

Kajian ini bertujuan mengukur tahap pengetahuan komuniti terhadap konsep perkhidmatan ekosistem dan mengenal pasti sumbangannya kepada kehidupan komuniti atau penduduk di kawasan Kuala Sepetang, Perak. Kaedah kuantitatif iaitu melalui kaedah tinjauan yang menggunakan borang soal selidik diguna pakai dalam mendapatkan maklum balas komuniti setempat. Responden kajian terdiri daripada komuniti tempatan sekitar kawasan Kuala Sepetang, Perak. Responden dipilih secara rawak mengikut kampung-kampung yang terdapat di kawasan tersebut yang terdiri daripada latar belakang yang berbeza. Sejumlah 249 borang soal selidik telah diedarkan meliputi soalan-soalan yang dibahagikan kepada beberapa bahagian seperti profil demografi responden, status ekonomi responden, status sosial responden, pengetahuan tentang perkhidmatan ekosistem serta sumbangan yang diperolehi daripada ekosistem berdasarkan skala Likert iaitu "sangat tidak setuju", "tidak setuju", "tidak pasti", "setuju" dan "sangat setuju". Dalam mengukur tahap pengetahuan penduduk mengenai ES, sebanyak 23 item soalan telah dibangunkan mengandungi keempat-empat jenis perkhidmatan ekosistem iaitu perkhidmatan sokongan, perkhidmatan kawal atur, perkhidmatan pembekalan dan perkhidmatan budaya. Indeks Kepentingan Relatif (RII) digunakan dalam kajian ini bagi mengukur tahap pengetahuan komuniti mengenai perkhidmatan ekosistem. Kaedah ini pernah digunakan dalam beberapa kajian sebelum ini seperti kajian oleh Akrofi et al. (2019) dan Somiah et al. (2015).

\section{Hasil dan perbincangan}

\section{Profil demografi responden}

Jadual 2 menunjukkan profil demografi responden yang diperoleh di Kuala Sepetang, Perak. Sejumlah 249 responden telah melibatkan diri dalam soal selidik yang dijalankan. Seramai 114 orang responden adalah lelaki manakala 135 orang lagi merupakan responden wanita. Terdapat lima jenis kumpulan umur iaitu yang berumur 20 tahun ke bawah, berumur 21 hingga 30 tahun, berumur 31 hingga 40 tahun, berumur 41 hingga 50 tahun dan 51 tahun ke atas. Berdasarkan keputusan, didapati golongan yang berumur 51 tahun ke atas telah terpilih sebagai responden iaitu 82 orang manakala di peringkat umur 20 tahun ke bawah mencatat jumlah responden yang sedikit disoal selidik iaitu 10 orang. Dari segi tahap pendidikan, kebanyakan responden mempunyai tahap pendidikan di sekolah menengah iaitu 143 orang responden $(57.43 \%)$, manakala bagi tahap pendidikan sekolah rendah sebanyak 68 orang responden $(27.31 \%), 24$ orang responden yang mempunyai tahap pendidikan pengajian tinggi atau kolej (9.64\%) dan 11 orang responden lagi (4.42\%) tiada pendidikan formal.

Majoriti responden tidak bekerja atau merupakan suri rumah iaitu seramai 81 orang (32.53\%) bagi kajian ini. Manakala responden yang bekerja dalam bidang pengeluaran seperti operator dan buruh, seramai 23 orang (9.24\%), bidang pekerjaan pertanian, ternakan dan perhutanan pula sebanyak 32 orang responden (12.85\%) begitu juga dengan bidang 
pekerjaan perkhidmatan. Di samping itu, terdapat 46 orang responden (18.47\%) yang bekerja dalam bidang jualan dan 6 orang responden $(2.41 \%)$ yang berkerja sebagai perkerja pentadbiran dan pengurusan, dan 29 orang responden (11.65\%) yang bekerja dalam bidang profesional dan teknikal. Majoriti responden mempunyai pendapatan bulanan dalam RM501 RM1500 iaitu 55.02 peratus (137 orang). Manakala jumlah pendapatan bulanan yang bawah daripada RM 500 adalah sebanyak 15.26 peratus (38 orang) dan responden yang mempunyai pendapatan bualanan yang melebihi RM1500 adalah 29.72 peratus ( 74 orang). Oleh itu, dapat disimpulkan bahawa kebanyakan responden yang telah disoal selidik mempunyai status ekonomi yang berpendapatan sederhana.

Jadual 2. Profil demografi responden

\begin{tabular}{|c|c|c|}
\hline Profil Demografi (N=249) & Frekuensi & $\%$ \\
\hline \multicolumn{3}{|l|}{ Jantina } \\
\hline Lelaki & 114 & 45.80 \\
\hline Wanita & 135 & 54.20 \\
\hline \multicolumn{3}{|l|}{ Umur } \\
\hline$<20$ tahun & 10 & 4.00 \\
\hline $20-30$ tahun & 72 & 28.90 \\
\hline $31-40$ tahun & 40 & 16.10 \\
\hline $41-50$ tahun & 45 & 18.10 \\
\hline$>51$ tahun & 82 & 32.90 \\
\hline \multicolumn{3}{|l|}{ Tahap Pendidikan* } \\
\hline Sekolah rendah & 68 & 27.31 \\
\hline Sekolah menengah & 143 & 57.43 \\
\hline Universiti/kolej/institusi & 24 & 9.64 \\
\hline Tiada pendidikan formal & 11 & 4.42 \\
\hline Lain-lain & 3 & 1.20 \\
\hline \multicolumn{3}{|l|}{ Jenis Pekerjaan* } \\
\hline Profesional/teknikal & 29 & 11.65 \\
\hline Pentadbiran/pengurusan & 6 & 2.41 \\
\hline Jualan & 46 & 18.47 \\
\hline Perkhidmatan & 32 & 12.85 \\
\hline Pertanian/ternakan/perhutanan & 32 & 12.85 \\
\hline Pengeluaran & 23 & 9.24 \\
\hline Tidak bekerja/suri rumah & 81 & 32.53 \\
\hline \multicolumn{3}{|l|}{ Jumlah Pendapatan (RM)* } \\
\hline$<500$ & 38 & 15.26 \\
\hline $501-1500$ & 137 & 55.02 \\
\hline $1501-3000$ & 52 & 20.88 \\
\hline $3001-5000$ & 17 & 6.84 \\
\hline $5001-10000$ & 3 & 1.20 \\
\hline$>10000$ & 2 & 0.80 \\
\hline
\end{tabular}

* dibundarkan kepada nombor bulat yang terdekat

\section{Tahap pengetahuan komuniti mengenai Konsep Perkhidmatan Ekosistem (ES)}

Nilai RII yang diperolehi menunjukkan pengetahuan responden di Kuala Sepetang tidak mempunyai banyak perbezaan. Kajian mendapati bahawa tahap pengetahuan penduduk mengenai perkhidmatan ekosistem adalah baik kerana kesemua nilai indeks melebihi nilai 0.6. Bagi kategori perkhidmatan sokongan, lima item dibangunkan iaitu meliputi kesuburan tanih, kandungan nutrien dalam tanah, kepelbagaian biologi, dan alam sekitar semula jadi. Dapatan kajian menunjukkan bahawa pengetahuan penduduk mengenai perkhidmatan sokongan adalah tinggi. Nilai RII yang paling tinggi menunjukkan pengetahuan penduduk 
juga adalah tinggi. Dalam perkhidmatan sokongan, nilai RII yang paling tinggi adalah 0.84 (E1) manakala terdapat dua soalan yang mempunyai nilai RII yang sama dan merupakan nilai terendah dalam kelima-lima soalan berikut iaitu 0.78 (E2 dan E3) (Rajah 1). Secara keseluruhannya, tahap nilai pengetahuan penduduk mengenai perkhidmatan sokongan adalah 0.80 (rujuk Rajah 2).

Bagi perkhidmatan kawal atur pula, terdapat enam item yang berkaitan suhu kawasan, udara, air bersih, dan mengawal bencana. Nilai 0.84 (E6) merupakan nilai RII yang paling tinggi manakala 0.70 merupakan nilai yang paling rendah bagi kategori perkhidmatan kawal atur (Rajah 1). Walau bagaimanapun, dapatan menunjukkan pengetahuan komuniti mengenai perkhidmatan kawal atur masih lagi tinggi. Manakala secara keseluruhannya, tahap pengetahuan komuniti mengenai perkhidmatan kawal selia berdasarkan nilai RII adalah sebanyak 0.76 (Rajah 2). Tahap pengetahuan komuniti mengenai perkhidmatan pembekalan diuji berdasarkan item seperti kewujudan biodiversiti, sumber makanan, bekalan air, sumber alam semula jadi. Hasilnya menunjukkan bahawa nilai RII bagi tahap pengetahuan komuniti juga masih tinggi. Hal ini bermakna pengetahuan komuniti mengenai perkhidmatan pembekalan juga tinggi. Terdapat satu nilai RII yang paling tinggi iaitu 0.86 (E14) (Rajah 1).

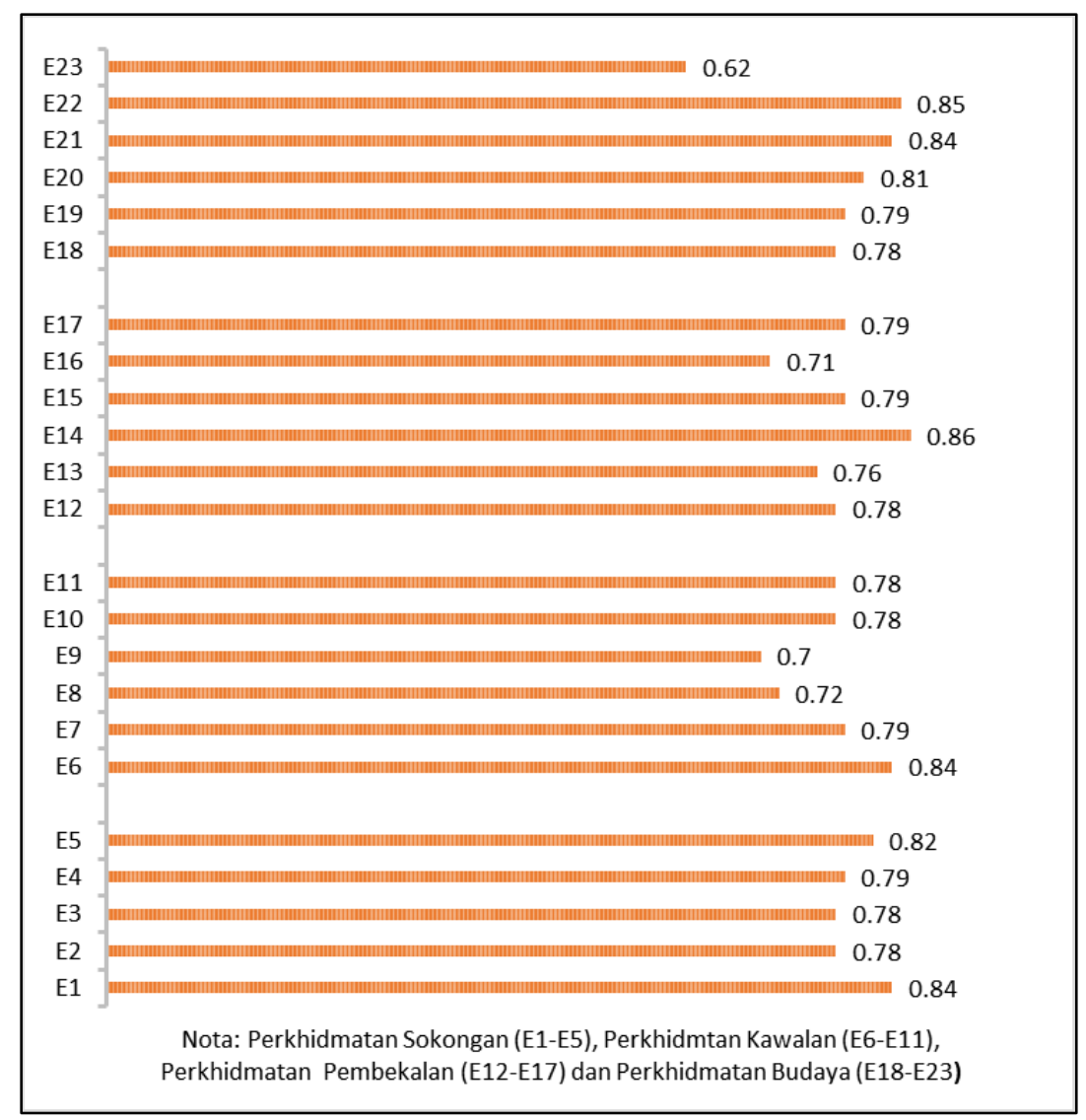

Rajah 1. Indeks kepentingan relatif (RII) bagi tahap pengetahuan responden mengenai konsep perkhidmatan ekosistem

Seterusnya, kategori perkhidmatan budaya meliputi lima item bagi menguji tahap pengetahuan komuniti mengenai perkhidmatan budaya dalam kehidupan seperti nilai estetika, rekreasi, riadah dan keagamaan. Dapatan kajian menunjukkan bahawa pengetahuan komuniti mengenai perkhidmatan budaya juga adalah baik dan nilai purata RII secara keseluruhan bagi kategori ini adalah 0.78 (Rajah 2). Pengetahuan penduduk terhadap perkhidmatan ekosistem adalah tinggi kerana, perkhidmatan ekosistem telah menyediakan dan membantu penduduk 
secara tidak langsung seperti membersihkan udara supaya dapat bernafas dengan baik, dapat menggunakan sumber air sebagai minuman, membekalkan bekalan makanan yang sering digunakan dalam kehidupan harian (Summers et al., 2018). Kesan daripada manfaat ini, membawa kepada pengetahuan penduduk terhadap perkhidmatan ekosistem.

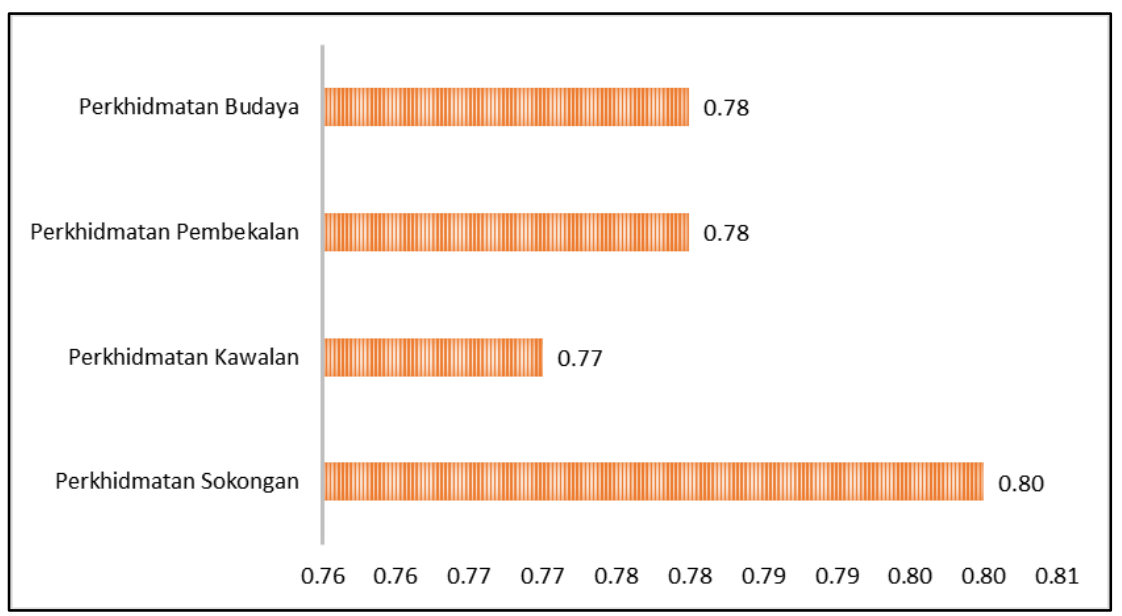

Rajah 2. Purata indeks kepentingan relatif (RII) mengikut kategori perkhidmatan ekosistem

\section{Sumbangan perkhidmatan ekosistem terhadap kesejahteraan hidup komuniti}

Penggunaan manfaat daripada sumber ekosistem semula jadi dan alam sekitar ditunjukkan dalam Rajah 3. Berdasarkan kajian yang dijalankan, beberapa ekosistem semula jadi yang terdapat di sekitar kawasan kajian telah dikenal pasti iaitu laut, paya bakau, belukar, hutan, tasik, sungai, dan tanah di sekitar tempat tinggal komuniti. Majoriti manfaat dan sumbangan daripada ekosistem yang terdapat di Kuala Sepetang adalah melalui perkhidmatan pembekalan yang turut selari dengan dapatan kajian sebelum ini di mana komuniti luar bandar meletakkan nilai yang lebih pada kategori perkhidmatan ini (Aguado et al., 2018). Ekosistem laut menyumbang perkhidmatan berbentuk pembekalan kepada komuniti di Kuala Sepetang dengan sejumlah 168 responden $(67.5 \%)$ menyatakan bahawa sumbangan utama ekosistem laut adalah daripada jenis makanan seperti ikan, udang, ketam, sotong, ketam, kerang dan sumber laut lain. Tambahan juga, ekosistem laut turut memberi sumbangan dalam sektor pelancongan dan rekreasi yang dikategorikan melalui manfaat perkhidmatan ekosistem budaya.

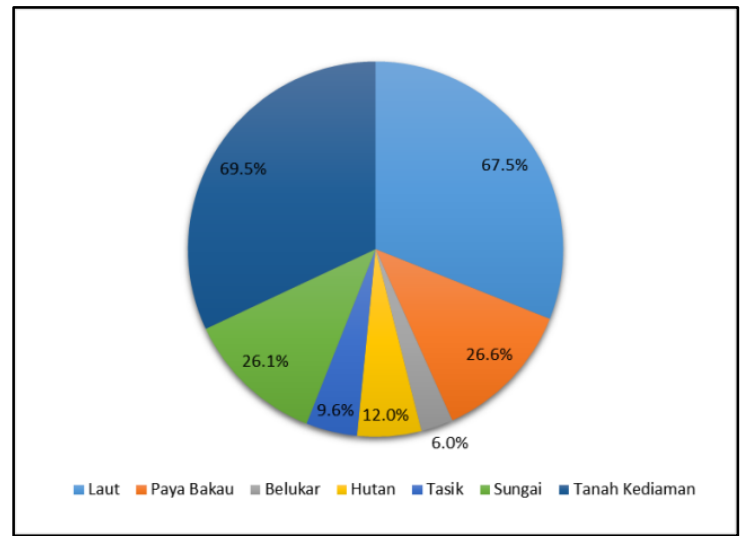

Rajah 3. Peratusan penggunaan manfaat sumber alam sekitar 
Bagi ekosistem paya bakau pula, manfaat atau sumbangan paling dominan yang diterima oleh komuniti Kuala Sepetang adalah dalam bentuk perkhidmatan pembekalan. Contohnya, seramai 69 orang responden (26.6\%) menyatakan bahawa ekosistem paya bakau berhampiran kawasan kediaman mereka menyediakan pelbagai sumber protein dan makanan seperti ikan, siput dan lokan. Ekosistem paya bakau juga menyediakan kayu yang boleh digunakan untuk pembinaan, sebagai arang kayu dan bahan bakar (kayu api). Manakala enam orang responden turut menyatakan bahawa ekosistem paya bakau adalah berpotensi untuk dijadikan sebagai pusat rekreasi seperti tempat pembiakan kelip-kelip yang menjadi tarikan pelancong untuk datang ke Kuala Sepetang. Sebanyak 15 orang responden $(6.0 \%)$ pula menyatakan bahawa kawasan belukar menyediakan sumber makanan seperti buah-buahan tempatan dan sumber kayu dan tumbuhan lain seperti rotan dan paku-pakis.

Selain itu, seramai 30 orang responden $(12.0 \%)$ pula menyatakan bahawa ekosistem hutan telah menyediakan pelbagai sumbangan kepada kehidupan mereka iaitu melalui penyediaan sumber ubat-ubatan, herba, ulam-ulaman, tanaman kelapa sawit, dan sebagainya. Ekosistem hutan juga berpotensi menjadi pusat pelancongan apabila ekosistem ini dijadikan hutan simpan dan menjadi tempat tumpuan untuk beriadah. Menurut Jenkins dan Schaap (2018); Kalaba (2013) mengatakan bahawa ekosistem hutan menyediakan pelbagai manfaat yang boleh dinikmati oleh masyarakat seperti serangga dan haiwan yang boleh dimakan, buah-buahan asli, sayur-sayuran liar dan madu yang banyak membantu penduduk dalam kehidupan harian. Hal ini dapat dibuktikan dengan kajian Summers et al. (2018) mendapati penduduk luar bandar di Amerika Latin, Afrika dan Asia memperolehi sebanyak 20 peratus dan 28 peratus daripada ekosistem hutan untuk menambahkan struktur ekonomi keluarga.

Ekosistem tasik juga tidak terkecuali dalam memberi sumbangan kepada kehidupan penduduk iaitu $9.6 \%$ responden berpendapat bahawa ekosistem tasik dan persekitarannya telah menghasilkan udara yang segar dan bersih, serta menawarkan sumber air bersih dan tempat untuk beriadah dan rekreasi. Ekosistem tasik ini juga bukan sahaja penting kepada komuniti setempat malah menyumbang kepada peningkatan jumlah pelawat dari luar kawasan yang ingin menikmati keunikan ekosistem semula jadi yang terdapat di Kuala Sepetang. Oertli dan Parris (2019) menyatakan peranan utama tasik dalam kehidupan manusia adalah sebagai habitat hidupan aquatik (sumber protein), nilai estetika, pendidikan alam sekitar dan aktiviti rekreasi. Sebanyak $26.1 \%$ responden menyatakan ekosistem sungai telah menyediakan perkhidmatan pembekalan dalam kehidupan mereka. Sumbangan yang mereka dapati daripada ekosistem sungai adalah seperti sumber protein (ikan, udang, ketam), air bersih dan tanaman dapur (sayur-sayuran).

Selain itu, tanah di sekitar kediaman mereka juga turut memberi sumbangan kepada kehidupan penduduk. Hasil dapatan telah membuktikan bahawa $69.5 \%$ responden telah menggunakan sumbangan yang disediakan oleh tanah di sekitar kediaman mereka seperti sayur-sayuran, buah-buahan, ulam-ulaman, tanaman herba, rempah ratus dan tanaman kontan yang tergolong dalam kategori makanan. Olunga et al. (2013); Uniyal dan Singh (2012) dalam kajiannya mengatakan alam sekitar dan sumber semula jadi memainkan peranan penting dalam menyediakan manfaat yang dapat menyokong kehidupan manusia khususnya dalam penyediaan makanan, pengawal aturan iklim, kitaran nutrien dan sebagainya. Justeru, salingkait hubungan alam sekitar dengan komuniti setempat terpancar melalui kehidupan penduduk Kuala Sepetang yang menitikberatkan peranan ekosistem dan hasil daripada perkhidmatan ekosistem dalam membantu mereka untuk menjalankan kehidupan harian. Angelsen et al. (2011) dan Kandel et al. (2018) mengatakan bahawa alam sekitar semula jadi memberi sumbangan besar kepada kehidupan manusia. Jadi, pemeliharaan dan pemuliharaan alam sekitar dan sumber semula jadi perlu diwujudkan dalam kalangan penduduk supaya dapat menjamin fungsi dan peranannya yang akan terus digunakan oleh generasi yang akan 
datang. Jadual 3 menunjukkan ringkasan sumbangan perkhidmatan ekosistem kepada kehidupan penduduk di Kuala Sepetang.

Jadual 3. Sumbangan Perkhidmatan Ekosistem kepada Kehidupan Penduduk di Kuala Sepetang

\begin{tabular}{|c|c|c|c|c|c|c|c|c|c|}
\hline Ekosistem & & Laut & Paya & Belukar & Hutan & Tasik & Sungai & $\begin{array}{l}\text { Tanah } \\
\text { Lapang }\end{array}$ & $\begin{array}{l}\text { Tanah } \\
\text { Sekitar } \\
\text { Kediaman }\end{array}$ \\
\hline \multirow{2}{*}{\multicolumn{10}{|c|}{$\begin{array}{l}\text { Perkhidmatan Sub-Kategori } \\
\text { a) Perkhidmatan Pembekalan }\end{array}$}} \\
\hline & & & & & & & & & \\
\hline \multirow[t]{4}{*}{ Makanan } & Tanaman & & & l & I & & & I & I \\
\hline & $\begin{array}{l}\text { Tanaman } \\
\text { Dapur } \\
\text { Ternakan }\end{array}$ & & & & & I & I & I & I \\
\hline & $\begin{array}{l}\text { Tangkapan } \\
\text { Perikanan }\end{array}$ & I & I & & I & & I & & \\
\hline & $\begin{array}{l}\text { Tumbuhan } \\
\text { liar dan } \\
\text { Pengeluaran } \\
\text { makanan } \\
\text { haiwan }\end{array}$ & & & l & & & & & \\
\hline \multirow[t]{2}{*}{ Serat } & Kayu & & I & & I & & & & \\
\hline & Kayu api & & l & & & & & & \\
\hline $\begin{array}{l}\text { Biokimia, ubatan } \\
\text { semula jadi dan } \\
\text { farmaseutikal }\end{array}$ & & & & & I & & & & \\
\hline Air Bersih & & & & & & I & I & & \\
\hline \multicolumn{10}{|c|}{ b) Perkhidmatan Kawal Atur } \\
\hline $\begin{array}{l}\text { Peraturan } \\
\text { Kualiti Udara }\end{array}$ & & & & & & I & & & \\
\hline \multicolumn{10}{|c|}{ c) Perkhidmatan Budaya } \\
\hline $\begin{array}{l}\text { Rekreasi dan } \\
\text { eko- } \\
\text { pelancongan }\end{array}$ & & & I & & I & I & & I & \\
\hline
\end{tabular}

\section{Penggunaan sumber perkhidmatan ekosistem berdasarkan jarak dari rumah}

Jadual 4 menunjukkan peratusan penggunaan sumber perkhidmatan ekosistem berdasarkan jarak dari rumah responden di Kuala Sepetang. Hasil kajian mendapati taburan jarak bagi penduduk mendapatkan sumber ekosistem semula jadi adalah tidak sekata. Hal ini adalah kerana peratusan penggunaan sumber adalah berbeza bagi setiap sumber ekosistem mengikut jarak tertentu. Majoriti responden mendapatkan hasil semula jadi dalam lingkungan jarak yang berdekatan dengan rumah masing-masing iaitu di bawah lingkungan lima kilometer sahaja. Kebanyakan sumber semulajadi yang diperolehi dalam lingkungan jarak ini adalah dari ekosistem laut (71.3\%), paya (78.0\%), belukar (91.0\%), hutan (92.6\%), sungai $(93.7 \%)$, tanah lapang (89.5\%) dan tanah sekitar kediaman (100.0\%). Selain itu, hasil yang didapati daripada ekosistem tasik menunjukkan bahawa peratusan yang tinggi bagi lingkungan jarak yang melebihi sepuluh kilometer. Hal ini memberi gambaran bahawa lokasi tasik dalam kajian kes ini adalah jauh daripada lokasi rumah responden yang menyebabkan peratusan 
penggunaan sumber ekosistem semula jadi dari kawasan tasik adalah sangat kurang dalam lingkungan jarak yang terdekat berbanding sumber semula jadi yang lain. Dalam kajian Ngang (2015); Phongkaranyaphat et al. (2017) dan Xu et al. (2015), mereka mendapati bahawa manusia yang berdekatan dengan sumber semula jadi lebih kerap menggunakan sumber tersebut dan memanfaatkannya dalam kehidupan harian mereka. Walau bagaimanapun, setiap sumber semula jadi masih diperlukan tidak kira berada dalam lingkungan jarak yang dekat atau pun lebih jauh daripada kediaman mereka. Hal ini adalah kerana setiap sumber semula jadi memberikan faedah yang berbeza kepada mereka.

Jadual 4. Peratusan penggunaan sumber ekosistem berdasarkan jarak sumber dari rumah

\begin{tabular}{|c|c|c|c|c|c|c|c|c|}
\hline \multirow[b]{2}{*}{$\begin{array}{l}\text { Jarak sumber } \\
\text { dari rumah } \\
\text { (km) }\end{array}$} & \multicolumn{8}{|c|}{ Ekosistem [\%] } \\
\hline & Laut & Paya & Belukar & Hutan & Tasik & Sungai & $\begin{array}{l}\text { Tanah } \\
\text { Lapang }\end{array}$ & $\begin{array}{l}\text { Tanah } \\
\text { Sekitar } \\
\text { Kediaman }\end{array}$ \\
\hline$<5$ & 71.3 & 78.0 & 91.0 & 92.6 & 20.8 & 93.7 & 89.5 & 100.0 \\
\hline $5-10$ & 25.2 & 16.0 & - & 7.4 & 12.5 & 4.8 & 10.5 & - \\
\hline$>10$ & 3.5 & 6.0 & 9.0 & - & 66.7 & 1.5 & - & - \\
\hline Jumlah & 100.0 & 100.0 & 100.0 & 100.0 & 100.0 & 100.0 & 100.0 & 100.0 \\
\hline
\end{tabular}

\section{Kesimpulan}

Perkembangan sesebuah kawasan yang semakin pesat membangun dan drastik kini telah memberi implikasi negatif kepada manusia dan alam sekitarnya khususnya dalam penyediaan sumbangan daripada perkhidmatan ekosistem. Kemusnahan ekologi sudah pastinya tidak dapat dielakkan demi memenuhi keperluan pembangunan dan kemajuan ciptaan manusia. Bagi memastikan segala perancangan, perkembangan dan perlaksanaan terhadap sesuatu pembangunan seiring dengan keperluan penjagaan ekosistem dan alam sekitar, maka kerjasama daripada semua pihak pemegang taruh serta agensi terlibat adalah sangat penting dan kritikal. Komuniti itu sendiri sebenarnya berupaya dalam menguruskan serta memastikan sumbangan yang disediakan oleh ekosistem sekitar dapat dinikmati dengan baik. Sehubungan itu, tahap pengetahuan komuniti setempat mengenai alam sekitar khususnya manfaat besar daripada ekosistem seperti melalui konsep perkhidmatan ekosistem adalah penting dalam memastikan setiap elemen ekosistem semula jadi sentiasa dipulihara dan dipelihara. Bukan itu sahaja, pengetahuan tentang perkhidmatan ekosistem dalam kalangan komuniti setempat pula akan mendorong kepada penghargaan yang lebih tinggi terhadap ekosistem semula jadi yang terdapat di kawasan sekitar tempat tinggal mereka. Oleh itu, manfaat dan sumbangan berdasarkan keempat-empat kategori perkhidmatan ekosistem iaitu perkhidmatan pembekalan, kawal atur, sokongan dan budaya dapat dikenal pasti dengan lebih menyeluruh dan seterusnya dijadikan potensi yang baik untuk meningkatkan kepentingannya dalam menambahkan pendapatan, ekonomi serta sara diri komuniti setempat. Akhirnya, kualiti hidup dan kesejahteraan komuniti setempat yang khususnya mendiami kawasan luar bandar seperti komuniti di Kuala Sepetang akan menjadi lebih baik.

\section{Penghargaan}

Kami menyatakan pengiktirafan dan penghargaan kepada Universiti Sains Malaysia untuk pembiayaan geran penyelidikan ini RUI (1001/PHUMANITI/8016002) yang bertajuk "Bundle Urban Green-Blue Space Benefits: Development of Education for Sustainable Development (ESD) Module for Sustainable urban Planning". 


\section{Rujukan}

Angelsen, A., Wunder, S., Babigumira, R., Blecher, B., Börner, J., \& Smith-Hall, C. (2011). Environmental incomes and rural livelihoods: a global-comparative assessment. Paper Presented at 4th Wye Global Conference, (3), 17. Retrieved from http://typo3.fao.org/fileadmin/templates/ess/pages/rural/wye_city_group/2011/document s/session4/Angelsen_Wunder_Babigumira_Belcher_Birner__Smith-Hall-Paper.pdf

Aguado, M., González, J.A., López-Santiago, C., \& Montes, C. (2018). Exploring subjective well-being and ecosystem services perception along a rural-urban gradient in the high Andes of Ecuador. Ecosystem services, 34, 1-10.

Ahammad, R., Stacey, N., \& Sunderland, T.C. (2019). Use and perceived importance of forest ecosystem services in rural livelihoods of Chittagong Hill Tracts, Bangladesh. Ecosystem services, 35, 87-98.

Akrofi, Mark M., Sarpong H. Antwi, \& Jabulani R. Gumbo. (2019). Students in climate action: A study of some influential factors and implications of knowledge gaps in Africa. Environments, 6(2), 12.

Chan R.Y.K. \& Lau, L.B.Y. (2000). Antecedents of Green Purchases: A survey in China. Journal of Consumer Marketing, 17(4), 338-357.

Crossman, N.D., Burkhard, B., Nedkov, S., Willemen, L., Petz, K., Palomo, I., ... Maes, J. (2013). A blueprint for mapping and modelling ecosystem services, 4, 4-14. doi:10.1016/j.ecoser.2013.02.001

Cruz-Garcia, G.S., Sachet, E., Blundo-Canto, G., Vanegas, M., \& Quintero, M. (2017). To what extent have the links between ecosystem services and human well-being been researched in Africa, Asia, and Latin America? Ecosyst. Serv., 25, 201-212.

Delgado, L.E., \& Marín, V.H. (2016). Well-being and the use of ecosystem services by rural households of the Río Cruces watershed, southern Chile. Ecosyst. Serv., 21, 81-91.

Duraiappah, A.K. (2011). Ecosystem services and human well-being: Do global findings make any sense? BioScience, 61(1), 7-8. doi:10.1525/bio.2011.61.1.2

Eustafor, \& Patterson, T. (2011). Ecosystem Services in European State Forests. The European State Forest Association (EUSTAFOR), (June), 40.

Felix, M., \& Burkhard, B. (2012). The indicator side of ecosystem services. Ecosystem Services, 1, 26-30. doi:10.1016/j.ecoser.2012.06.001

Fru Delvis Ngang. (2015). The contribution of community-based natural resources management to livelihoods, conservation and governance in Cameroon. A comparative assessment of three community forests. West Africa, Pan African Institute for Development.

Haines-young, R., \& Potschin, M. (2013). Common International Classification of Ecosystem Services ( CICES ): Consultation on Version 4, August-December 2012. UK.

Hashim, N.M., Sakawi, Z., Choy, L.K., Jaafar, M., Rose, R.A.C., \& Ahmad, N.H. (2019). Tahap kesedaran komuniti pinggir pantai terhadap kenaikan aras laut. Geografia: Malaysian Journal of Society and Space, 15(2), 69-83.

Hasliza Abdul Rahman, \& Rohasliney Hashim. (2010). Pemeliharaan dan Pemuliharaan Alam Sekitar di Malaysia. Pulau Pinang, Universiti Sains Malaysia.

Hapsari, A. (2010). Assessing and mapping ecosystem services in assessing and mapping ecosystem services in Offinso. Belgium, Ghent University.

Hou, Y., Zhou, S., Burkhard, B., \& Müller, F. (2014). Socioeconomic influences on biodiversity, ecosystem services and human well-being: a quantitative application of the DPSIR model in Jiangsu, China. Science of the Total Environment, 490, 1012-1028.

Howe, C., Suich, H., Vira, B., \& Mace, G. M. (2014). Creating win-wins from trade-offs ? Ecosystem services for human well-being: A meta-analysis of ecosystem service trade- 
offs and synergies in the real world. Global Environmental Change, 28, 263-275. doi:10.1016/j.gloenvcha.2014.07.005

Jamilah Ahmad, Hasrina Mustafa, Hamidah Abdul Hamid, \& Juliana Abdul Wahab. (2011). Pengetahuan, sikap dan amalan masyarakat malaysia terhadap isu alam sekitar. Jurnal Akademika, 81(3): 103-115.

Jenkins, M., \& Schaap, B. (2018). Forest ecosystem services - Background analytical study. United Nations Forum on Forests, (April). Retrieved from http://www.unece.org/ fileadmin/DAM/timber/meetings/20151102/English_new_FAO_logo/ECE_TIM_2015_ 6_FO_EFC_15_6.pdf

Jose, S. (2009). Agroforestry for ecosystem services and environmental benefits: An overview. Agroforestry Systems, 76(1), 1-10. doi:10.1007/s10457-009-9229-7

Kalaba , F.K. (2013). Forest ecosystem services, rural livelihoods and carbon storage in Miombo woodland in the Copperbelt region of Zambia. University of Leeds.

Kandel, P., Tshering, D., Uddin, K., Lhamtshok, T., Aryal, K., Karki, S., ... Chettri, N. (2018). Understanding social-ecological interdependence using ecosystem services perspective in Bhutan, Eastern Himalayas. Ecosphere, 9(2).

Kandziora, M., Burkhard, B., \& Müller, F. (2013). Interactions of ecosystem properties, ecosystem integrity and ecosystem service indicators: A theoretical matrix exercise. Ecological Indicators, 28, 54-78. doi:10.1016/j.ecolind.2012.09.006

Kuhn, C. (2014). Assessing the provisioning ecosystem service food rice and its linkages to human well-being in Hai Duong and Vinh Phuc Province of Vietnam. Presented by Faculty of Agricultural and Nutritional Sciences. University of zu Kiel, Vietnam.

Laroche, M., Bergeron, J., \& Barbaro-Forleo, G. (2001). Targeting consumers who are willing to pay more for environmentally friendly products. Journal of consumer marketing, 18(6), 503-520.

Liu, S., Costanza, R., Farber, S., \& Troy, A. (2010). Valuing ecosystem services: theory, practice, and the need for a transdisciplinary synthesis. Annals of the New York Academy of Sciences, 1185(1), 54-78. Retrieved from http://onlinelibrary.wiley.com/doi/10.1111/ j.1749-6632.2009.05167.x/abstract

Liu, Y., Li, J., \& Zhang, H. (2012). An ecosystem service valuation of land use change in Taiyuan City, China. Ecological Modelling, 225, 127-132. doi:10.1016/ j.ecolmodel.2011.11.017

Millennium Ecosystem Assessment. (2005). Ecosystems and human well-being: Synthesis. Ecosystems, 5. doi:10.1196/annals.1439.003

Mohamad, F.B. \& Teoh Y.Y. (2006). Tahap keprihatinan alam sekitar dan amalan kepenggunaan hijau pengguna di Petaling Jaya, Selangor. Pertanika J. Soc. Sci. \& Hum. 14(2), 95-109.

Oertli, B., \& Parris, K.M. (2019). Review: Toward management of urban ponds for freshwater biodiversity. Ecosphere, 10(7).

Olunga M.A, Kavoi M.M., \& G. P. (2013). Assessment of factors influencing utilization of forest resources in Kipini division of Tana delta district, Kenya. University of Nairobi. Retrieved from http://erepository.uonbi.ac.ke/bitstream/handle/11295/56524/Olunga_ utilization of Forest.pdf? sequence $=3$

Ostrom, E. (2008). The Challenge of common-pool resources. Environment: Science and Policy for Sustainable Development, 50(4), 8-21. Retrieved from http://www.tandfonline.com/doi/abs/10.3200/ENVT.50.4.8-21

Patterson, T.M., \& Coelho, D.L. (2009). Ecosystem services: Foundations, opportunities, and challenges for the forest products sector. Forest Ecology and Management, 257, 16371646. doi:10.1016/j.foreco.2008.11.010

Phongkaranyaphat, K., Maiman, S., \& Asanok, L. (2017). Factors influencing people 
participation in community forest management in Phrae Province , North Thailand. International Journal of Agricultural Technology, 13, 1707-1713.

Price, C. (2014). Regulating and supporting services and disservices: customary approaches to valuation, and a few surprising results. New Zealand Journal of Forestry Science, 44(Suppl 1), S5. Retrieved from http://www.nzjforestryscience.com/content/44/S1/S5

Raman, F.I., \& Bakar, K.A. (2019). Amalan kelestarian alam sekitar dalam kalangan guru prasekolah. Geografia: Malaysian Journal of Society and Space, 15(2), 15-30.

Rasethe, M.T., Semenya, S.S., Potgieter, M.J., \& Maroyi, A. (2013). The utilization and management of plant resources in rural areas of the Limpopo Province, South Africa. Journal of Ethnobiology and Ethnomedice, 9(27), 1-8.

Roy Haines-Young, \& Potschin Marion. (2010). Common International Classification of Ecosystem Goods and Services (CICES): Consultation on Version 4, August-December 2012. EEA Framework Contract No EEA/IEA/09/003. Contract. doi:10.1038/nature 10650

Sekercioglu, C.H. (2010). Ecosystem functions and services. Conservation Biology for All, 45-72. doi:10.1093/acprof:oso/9780199554232.001.0001

Shackleton, C., Shackleton, S., Gambiza, J., Nel, E., Rowntree, K., \& Urquhart, P. (2008). Links between Ecosystem Services and poverty alleviation. Situation analysis for arid and semi-arid lands in southern Africa. Consortium on Ecosystems and Poverty in SubSaharan Africa (CEPSA).

Smith, N., Deal, R., Kline, J., Spies, T.A., Blahna, D., Patterson, T., \& Bennett, K. (2011). Ecosystem services as a framework for forest stewardship: Deschutes national forest overview. USDA Forest Service - General Technical Report PNW-GTR, 1-46. Retrieved from http://www.scopus.com/inward/record.url?eid=2-s2.0-80053993065\&partnerID $=40 \& \mathrm{md} 5=\mathrm{ab} 1 \mathrm{fd} 0 \mathrm{~d} 1 \mathrm{~b} 0293 \mathrm{fd} 559 \mathrm{f} 39394 \mathrm{c} 928 \mathrm{eedd}$

Sodhi, N.S., Lee, T.M., Sekercioglu, C.H., Webb, E.L., Prawiradilaga, D.M., Lohman, D.J., Pierce, N.E., Diesmos, A.C., Rao, M., \& Ehrlich, P.R. (2010). Local people value environmental services provided by forested parks. Biodivers. Conserv., 19(4),11751188.

Somiah, M.K., Osei-Poku, G., \& Aidoo, I. (2015). Relative importance analysis of factors influencing unauthorized siting of residential buildings in the Sekondi-Takoradi Metropolis of Ghana. Journal of building construction and planning Research, 3(03), 117.

Summers, J.K., Smith, L.M., Fulford, R.S., \& de Jesus Crespo, R. (2018). The role of ecosystem services in community well-being (pp. 401-411). In Levente Hufnagel (Eds.), Ecosystem Services and Global Ecology. London, IntechOpen. Retrieved from https://www.intechopen.com/books/advanced-biometric-technologies/liveness-detection -in-biometrics

Uniyal, S.K., \& Singh, R.D. (2012). Natural resources assessment and their utilization: Analyses from a Himalayan state. Environmental Monitoring and Assessment, 184(8), 4903-4919.

Vieira da Silva, L., Everard, M., \& Shore, R.G. (2014). Ecosystem services assessment at Steart Peninsula, Somerset, UK. Ecosystem Services, 10, 19-34. doi:10.1016/j.ecoser. 2014.07.008

Villamagna, A., \& Giesecke, C. (2014). Adapting human well-being frameworks for ecosystem service assessments across diverse landscapes. Ecology and Society, 19(1). doi:10.5751/ES-06173-190111

Watson, R.T., Rosswall, T., Steiner, A., Töpfer, K., Arico, S., \& Bridgewater, P. (2005). Ecosystems and human well-being. Ecosystems, 5(281), 1-100. doi:10.1196/annals. 1439.003 
Xu, D., Zhang, J., Rasul, G., Liu, S., Xie, F., Cao, M., \& Liu, E. (2015). Household livelihood strategies and dependence on agriculture in the mountainous settlements in the Three Gorges Reservoir Area, China. Sustainability, 7(5), 4850-4869. Retrieved from http://www.mdpi.com/2071-1050/7/5/4850/ 